\title{
Mineral-Geochemical Criteria to Gold and Silver Recovery for Geometallurgical Sampling Campaign on Primorskoe Gold-Silver Deposit
}

\author{
I. Anisimov ${ }^{(\bowtie)}$, A. Sagitova, O. Troshina, and I. Agapov \\ Technology Research Department, Polymetal Engineering JSC, \\ St-Petersburg, Russia \\ anisimovis@polymetal.ru
}

\begin{abstract}
Ore variability study at Primorskoe gold-silver deposit demonstrated wide variety of mineral composition and gold and silver recoveries with cyanadation. The ore consisted of quartz-feldspar veins, quartz-rhodonite, quartz-"pyrolusite", quartz-epidote-garnet and quartz-Mn-silicates/hydroxides. Todorokite, birnessite, rancieite were the most common among the last ones. Statistical analyses of chemical and mineral composition, parameters of cyanidation tests showed occurrence of three main ore types - feldspatic, manganese silicate and oxide. Gold recovery effected by locking in Fe-oxides. The highest silver recovery strongly correlated with feldspathic cluster and whiter sample color reflecting Ag mineral forms: acanthite and electrum. Ore with silicate Mn showed good recoveries of acanthite, electrum and iodargirite associated with Mn silicates. Main silver losses were connected with Mn-oxides content and dark ore coloration where Ag chemically bound in Mn-oxides. $\mathrm{Sr}$ and $\mathrm{Ba}$ content along with sample color were indications that could be used as a proxy for recovery in geometallurgical mapping and ore-sorting.
\end{abstract}

Keywords: Silver $\cdot$ Predictive recovery $\cdot$ Cyanidation $\cdot$ Manganese mineralization

\section{Introduction}

Primorskoe Au-Ag deposit is located in Omsukchan district of Magadan oblast, Russia. It formed by hydrothermal veins of various composition: Qu-Fsp-Chl with Ep, Qu$\mathrm{Rdn}-\mathrm{MnO}_{\mathrm{x}}, \mathrm{Qu}-\mathrm{MnO}_{\mathrm{x}}$ and $\mathrm{Qu}-\mathrm{Gar} \pm \mathrm{Wol}$. Noble metal mineralization represented with acantite, iodargirite, aurorite, jalpaite, pyrargyrite, electrum, kustelite and native silver and gold. Abundance of specific manganese oxides effected gold and silver extraction by cyanidation. The mineral composition study was aimed to define causes of possible gold and silver losses with cyanidation tails and possible ways to recover refractory silver. 


\section{Methods and Approaches}

72 individual and 57 composite geometallurgical samples of Primorskoe deposit were studied for chemical and mineral composition and cyanidation tests were performed. $\mathrm{Ag}$ varied from 176 to $36450 \mathrm{ppm}$ in individual samples and gold - from 0.01 to $113 \mathrm{ppm}$. Ag content range in the composite samples was 49-1509 ppm averaging $606 \mathrm{ppm}$ and $\mathrm{Au}-0.04-9.92 \mathrm{ppm}$ averaging $1.56 \mathrm{ppm}$.

Chemical composition was studied at ALS labs, Moscow. Au content was assayed by fire assay with atomic absorption finish, Ag and other 35 elements analyzed by ICPAES after four acid digestion.

Quantitative X-ray powder diffraction by Rietveld refinement (QXRD) was carried out using Bruker D8 Advanced diffractometer with Linxeye XE detector at Technology Research Department, Polymetal Engineering.

Statistical analysis was done on filtered data with Aitchison transformation using PCA, regression analyses and Pearson correlations in Cytoscape software.

\section{Results and Discussion}

Mineral composition of the sample significantly varied in quartz (up to 94\%), feldspar (up to 63\%), micas (illite and muscovite - up to 25\%). Epidote and piemontite formed up to $14.5 \%$, grossular and calderite - up to $8.9 \%$. Bustamite (up to $22.8 \%$ ), rhodonite (up to $14.6 \%$ ) and wollastonite (up to $16.7 \%$ ) were observed in some samples. Apatitemagnetite-titanite-vermiculite association was common in few samples. Manganese oxides contents ran up to $34.4 \%$.

Mn-mineralization presented in 18 minerals: silicates (piemontite, calderite, bustamite, rhodonite), carbonate (rhodochrosite), sulfide (alabandite), oxi-hydroxides. Todorokite, birnessite ( $7 \AA, 14-\AA$ and amorphous), rancieite well spread among the last ones. Manganite, pyrolusite, ramsdellite, jacobsite, bixbyite, pyrochroite, chalcophanite, coronadite, aurorite were less common.

Data population for multivariate statistical analyses included 103 following parameters of chemical and mineral composition, color (RGB, brightness - BRT, and darkness - DRN), material fineness $(\gamma+100)$, silicate and oxide $\mathrm{Mn}$ ratio (Mnsil/Mnox), 14 parameters of cyanidation conditions ( $\mathrm{NaCN}$ concentration in the pregnant solution - NaCNps; $\mathrm{NaCNc}$ and $\mathrm{CaO}$ consumption; final test $\mathrm{pH}-\mathrm{pHf}$; $\mathrm{Au}$ and Ag contents in pregnant solution and cake - AuPS, AgPS, AuK, AgK; Au and Ag recovery $-\varepsilon A u, \varepsilon A g$ and losses $--\varepsilon A u,-\varepsilon A g$ (Fig. 1). Pearson correlations revealed occurrence of two main geochemical and mineral clusters - whiter feldspathic (rockforming Ab-Olg-Chl) and darker manganese. Mgt-Tit-Ap-Vrm sub-cluster occurred in the feldspathic one showing accessory syenite mineralization. "Skarn" association (wollastonite, diopside, andradite, calcite, bustamite, rhodonite) and quartz vein (Qu, $\mathrm{SiO}_{2}, \mathrm{Cr}$ and Iron - grinding contaminants) were distinguished. Ag recovery and $\mathrm{NaCN}$ content in pregnant solution tied with color cluster. 


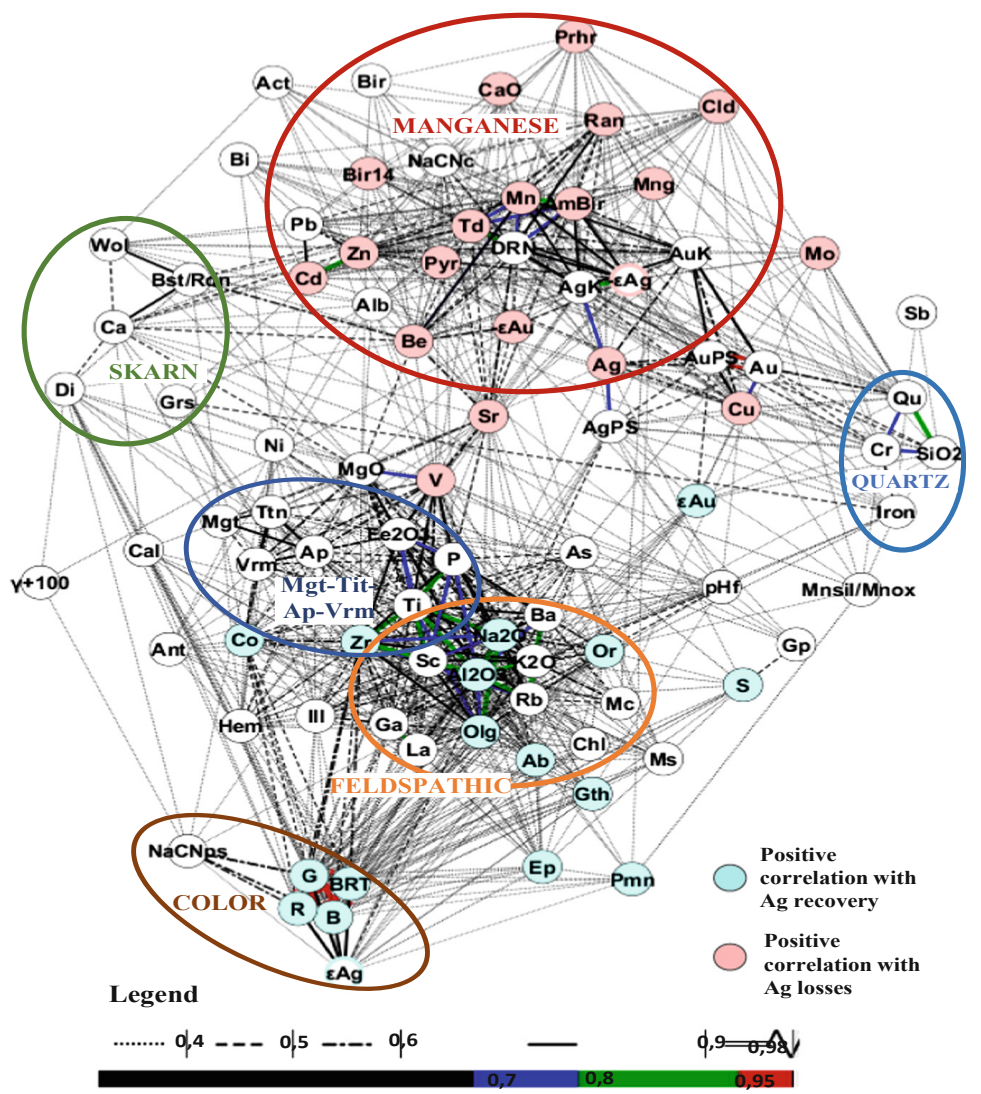

Fig. 1. Correlations between 88 transformed parameters of individual and composite samples of geometallurgical sampling campaign of Primorskoe deposit and proposed mineral association clusters. Legend shows Pearson correlation coefficient values

Reagents consumptions $(\mathrm{CaO}, \mathrm{NaCN})$ correlated with Mn-cluster, proving that ion exchange might take place during leaching. $\mathrm{Zn}, \mathrm{Cd}, \mathrm{Pb}$ tended to $\mathrm{Mn}$-cluster without connection to a specific Mn-oxide. Sr related to both main clusters equally reflecting isomorphic distribution in feldspathic gangue as well as in $\mathrm{MnO}_{\mathrm{x}}$.

Ag recovery demonstrated positive correlation with feldspathic cluster and sample white color (BRT). Ag losses had strong connection with $\mathrm{MnO}_{\mathrm{x}}$. Au recovery tied together with color and quartz, Au losses correlated with $\mathrm{MnO}_{\mathrm{x}}$ and locking.

PCA analysis showed same regularities. 6 principal components explained $54.78 \%$ of the total variance and described mineral composition (Fig. 2), Mn- and accessory mineralization, noble metal contents and recovery. PCA highlighted strong connection between Ag loses, todorokite and amorphous birnessite.

Regression Eq. (1) showed strong relation $\left(R^{2}=0.66\right)$ between silver recovery, color (BRT) and some elements contents (in ppm). Variables listed in the order of their significance: 


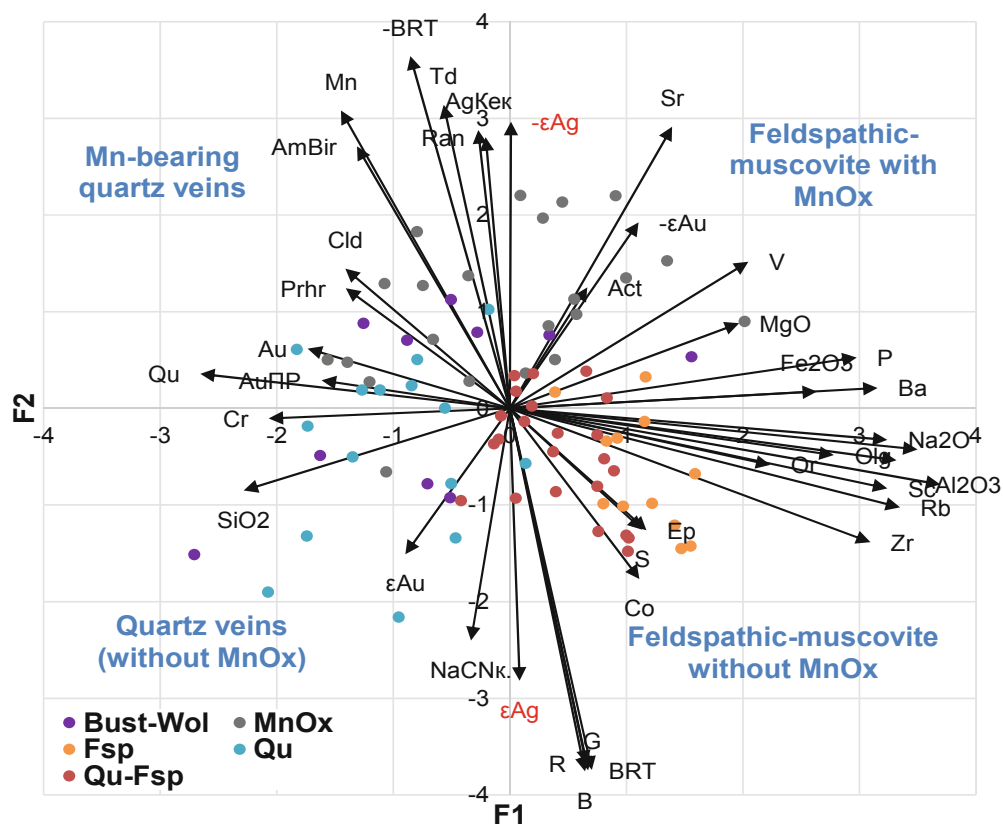

Fig. 2. Factor loadings and factor scores for factors 1 and 2 with their interpretation

$$
\begin{aligned}
& \varepsilon \mathrm{Ag}=18.24+0.47 \mathrm{BRT}+1.39 \mathrm{Al} 2 \mathrm{O} 3(\mathrm{wt} \%)-0.12 \mathrm{~V}+0.05 \mathrm{Sr}-3.45 \mathrm{Sc}- \\
& 0.01 \mathrm{Ag}-1.21 \mathrm{Mn}(\mathrm{wt} \%)+0.45 \mathrm{Ca}(\mathrm{wt} \%)+0.003 \mathrm{Cu}-0.13 \mathrm{Rb}+0.01 \mathrm{~S}
\end{aligned}
$$

\section{Conclusions}

Individual and composite samples of Primorskoe Au-Ag deposit demonstrated variety of mineral composition from high silica and feldspar to Mn-skarn association. Mn mineralization presented in silicates, oxides and hydroxides, carbonate, sulfide had great impact on Ag recovery. Wide range of vein gangue, ore and noble metal mineral associations were similar to ones characteristic for Dukat deposit, the largest silver deposit in Russia.

$\mathrm{Ag}$ mineral forms affected recovery rate from highest presented by acanthite, electrum in feldspatic association to the lowest locked in Mn-oxides, mainly in todorokite and birnessite. Ore sorting by color and element content can be used. 
Acknowledgements. The authors are grateful to Sergey Kubyshkin for performance of cyanidation tests and Boris Milman for scientific advices.

Open Access This chapter is licensed under the terms of the Creative Commons Attribution 4.0 International License (http://creativecommons.org/licenses/by/4.0/), which permits use, sharing, adaptation, distribution and reproduction in any medium or format, as long as you give appropriate credit to the original author(s) and the source, provide a link to the Creative Commons license and indicate if changes were made.

The images or other third party material in this chapter are included in the chapter's Creative Commons license, unless indicated otherwise in a credit line to the material. If material is not included in the chapter's Creative Commons license and your intended use is not permitted by statutory regulation or exceeds the permitted use, you will need to obtain permission directly from the copyright holder. 